\title{
Strategi Pengembangan Aspek Lingkungan di Titik Pandang Panenjoan dengan Berlandaskan Konsep Pariwisata Bertanggung Jawab
}

\author{
Irham Nur Prasetyo Wibowo \\ Universitas Gadjah Mada \\ Email: Irham.nur.p@mail.ugm.ac.id
}

\begin{abstract}
Panenjoan is one of the tourist destinations located within the Geopark Ciletuh-Palabuhanratu. This destination is located in the village of Tamanjaya, Ciemas District, Sukabumi Regency, West Java. Since the area was established as part of the Geopark Ciletuh-Palabuhanratu, an increasing number of tourists visit continues to happen every year. Negative effects can occur if the destination is not ready in accepting such a surge, especially environmental aspects. Therefore, the study aims to formulate a development strategy for Panenjoan view point based on the concept of responsible tourism that focused on environmental aspects. This research uses qualitative research methods with data derived from the results of focused group discussion or FGD, the field observation, and the study of the literature. Data analysis was done with the SWOT analysis and the results obtained are then elaborated in descriptive. The results obtained from this research is based on a matrix of IFAS and EFAS can note that the position of the internal and external Point of view Panenjoan tend to be weak and threatened with a score each amounting to 2.15 and 2.28. To address and minimize such threats and weaknesses, has drawn up recommendations that focus on environmental aspects of responsible tourism i.e. (1) conserving water aspect consisting of organic mulch-making training, partnership with agencies in the procurement of electronic water meter, increasing public awareness in conservation of water, and the involvement of travelers in the preservation of water. (2) The aspect of using energy efficiently which consists of working with agencies to procure light Light Emitting Diode (LED) as well as in the regular maintenance of electronic tools, and installation of the light sensor. (3) Reducing and managing waste aspect, namely waste management training, digitalization of information contents, procurement of simple recycling facility, and the separating wastes specifically.
\end{abstract}

Keywords: Panenjoan, Ciletuh-Palabuhanratu Geopark, responsible tourism, environment

\section{Pendahuluan}

Taman Bumi Ciletuh-Palabuhanratu adalah sebuah konsep manajemen pengelolaan kawasan yang menyerasikan keragaman geologi, hayati, dan budaya, melalui prinsip konservasi, edukasi, dan pembangunan yang berkelanjutan di 8 kecamatan di Kabupaten Sukabumil. Taman bumi ini memiliki potensi pariwisata yang kuat untuk dikembangkan menjadi salah satu destinasi unggulan di Jawa
Barat dan tingkat nasional. Kawasan Taman Bumi Ciletuh-Palabuhanratu dibagi menjadi 3 geoarea yaitu Geoarea Cisolok yang memiliki tema pergeseran jalur magmatik, kemudian Geoarea Jampang dengan tema bentang alam plato jampang, dan yang terakhir Geoarea Ciletuh yang bertemakan fosil subduksi.

Panenjoan merupakan atraksi wisata di 
Taman Bumi Ciletuh-Palabuhanratu yang paling ramai dikunjungi karena memiliki kelengkapan wisata yang lebih memadai dibandingkan dengan atraksi wisata lain, dapat dikatakan bahwa Panenjoan merupakan pusat dari aktivitas pariwisata di Desa Tamanjaya. Atraksi utama yang ditawarkan oleh Panenjoan adalah panorama Amfiteater Ciletuh dan Teluk Ciletuh. Pemandangan matahari terbenam dari titik ini merupakan salah satu hal utama yang diburu oleh wisatawan. Fasilitas pendukung berupa penginapan, rumah makan, tempat ibadah, dan toilet umum juga tersedia dengan baik di Panenjoan.

Jumlah kunjungan wisatawan ke Panenjoan menunjukkan peningkatan yang sangat pesat dengan rata-rata peningkatan sebesar $2.822 \%$ atau lebih kurang 28 kali lipat setiap tahun2. Tercatat ada 5 wisatawan yang mengunjungi Panenjoan sepanjang tahun 2013 dan terus mengalami peningkatan hingga menjadi 21.229 wisatawan pada bulan Juni tahun 2017. Semakin ramainya kunjungan wisatawan membuat Panenjoan menjadi lebih rentan rusak akibat perilaku wisatawan yang kurang bertanggung jawab apabila dibandingkan dengan atraksi wisata yang lebih sedikit dikunjungi. Terlebih dengan dikukuhkannya kawasan Taman Bumi Ciletuh-Palabuhanratu sebagai bagian dari UNESCO Global Geopark3.

Untuk meminimalkan dampak negatif dan menjaga kelestarian atraksi wisata ini untuk jangka panjang, diperlukan suatu strategi pengembangan yang sesuai dengan karakter atraksi wisata ini. Konsep Pariwisata Bertanggung Jawab merupakan salah satu konsep yang dapat diterapkan di Panenjoan. Konsep ini bertujuan untuk menciptakan pengalaman berkualitas tinggi bagi pengunjung, memperkuat masyarakat lokal, dan mengembangkan mata pencaharian di bidang pariwisata sembari menjaga lingkungan.

\section{Kerangka Teori}

Penelitian ini berfokus pada perumusan strategi pengembangan yang sesuai dengan konsep pariwisata bertanggung jawab di titik pandang Panenjoan yang merupakan salah satu atraksi wisata di Taman Bumi Ciletuh-Palabuhanratu. Sunaryo (2013: 160) mendefinisikan destinasi pariwisata sebagai suatu keterkaitan sistemik antar objek dan daya tarik wisata beserta dengan segenap unsur-unsur pendukungnya seperti aksesibilitas, amenitas, masyarakat setempat, dan unsur-unsur penunjang lainnya yang bekerja secara sinergis dalam satu kesatuan sistem yang saling menunjang dan melengkapi.

Suatu destinasi pariwisata memerlukan pengembangan untuk memenuhi 3 fungsi, yaitu menggalakan ekonomi, memelihara kepribadian bangsa dan kelestarian serta fungsi lingkungan hidup, dan memupuk rasa cinta tanah air dan bangsa (Joyosuharto, 1995: 46). Segenap pemangku kepentingan dan pelaku pengembangan di suatu destinasi pariwisata memiliki kewajiban untuk selalu mengupayakan terwujudnya kondisi integrasi atau simbiosis mutualisme antara kepariwisataan dan lingkungan setempat (Sunaryo, 2013: 42). Upaya pengembangan dengan model seperti ini disebut juga sebagai pembangunan kepariwisataan yang berkelanjutan atau sustainable tourism development. Salah satu jenis implementasi dari pembangunan kepariwisataan yang berkelanjutan adalah pengembangan dengan konsep pariwisata bertanggung jawab atau responsible tourism.

Diskusi mengenai konsep pariwisata bertanggung jawab telah dimulai sejak 30 tahun yang lalu. Krippendorf (1987: 174) menemukan bahwa wisatawan menjadi lebih rumit dalam memenuhi kebutuhannya dan industri harus mengadopsi praktik pemasaran yang lebih berorientasi lingkungan dan bertanggung jawab secara social untuk menjaga tingkat kepuasan di masa depan untuk pasar yang lebih menuntut dan tersegmen. Wheller (1990) mengidentifikasi bahwa konsep pariwisata bertanggung jawab muncul sebagai respon terhadap kekhawatiran pada dampak dari perkembangan pariwisata massal dan untuk membedakan bentuk pariwisata alternatif.

Berdasarkan Deklarasi Cape Town pada tahun 2002, pariwisata bertanggung jawab didefinisikan sebagai pariwisata yang menciptakan tempat yang lebih baik untuk manusia yang hidup di dalamnya dan tempat yang lebih baik untuk dikunjungi wisatawan. Pariwisata bertanggung jawab berfokus pada penyediaan pengalaman berwisata yang lebih baik bagi wisatawan dan kesempatan bisnis yang baik untuk menikmati kualitas hidup yang lebih baik melalui peningkatan manfaat sosial-ekonomi dan pengelolaan sumber daya alam (Spenceley et $a l, 2002)$. Literatur yang ada mengenai pariwisata 
bertanggung jawab mengungkapkan berbagai pemahaman yang bervariasi berdasarkan subjeknya apakah konsep, teori, atau praktik (Leslie, 2012); melibatkan berbagai pemangku kepentingan dan tujuan yang berbeda; atau menciptakan pariwisata yang lebih ramah lingkungan atau tempat yang lebih baik untuk ditinggali dan dikunjungi (RTP, 2002). Lebih lanjut, literatur yang ada berfokus pada konsumsi atau produksi yang bertanggung jawab (Budeanu, 2005; Stanford, 2008), mengeksplorasi hubungan antara wisatawan dan masyarakat lokal, dan mempertanyakan tanggung jawab individu melawan tanggung jawab sosial serta asumsi politik dan model tata kelola dibalik pertanggungjawaban (Bramwell et al., 2008; Hall, 2012)

Pariwisata bertanggung jawab mengajak individu-individu, organisasi, pemerintah, dan industri untuk mengambil tanggung jawab dalam setiap aksi yang mereka lakukan, dan dampak dari aksi mereka. Setiap yang terlibat harus bertanggung jawab dalam menciptakan keberlanjutan. Pariwisata bertanggung jawab dan pariwisata berkelanjutan dua konsep yang serupa karena memiliki tujuan yang sama, yaitu untuk menciptakan keberlanjutan dalam kegiatan pariwisata, sehingga keuntungan dari adanya kegiatan pariwisata bisa dirasakan dalam waktu yang lama (Manente et al, 2014: 4). Selain persamaan tujuan, kedua konsep ini berbagi pilar yang sama, yaitu integritas lingkungan, keadilan sosial, dan manfaat ekonomi lokal yang maksimal. Pariwisata berkelanjutan merupakan sebuah tujuan akhir yang ingin dicapai sedangkan pariwisata bertanggung jawab merupakan salah satu cara untuk mewujudkan tujuan tersebut (Goodwin, 2011).

\section{Metode}

\subsection{Jenis dan Sumber Data Penelitian}

Data primer dalam penelitian ini diperoleh melalui observasi lapangan, wawancara tidak terstruktur, dan focused group discussion (FGD) dengan pemangku kepentingan yang terlibat dalam aktivitas pariwisata di Titik Pandang Panenjoan, antara lain Badan Pengelola Geopark-Ciletuh Palabuhanratu, PAPSI sebagai organisasi masyarakat, perangkat desa, pelaku wisata di sekitar lokasi penelitian, dan juga masyarakat lokal.
Focused Group Discussion (FGD) atau diskusi kelompok terarah adalah metode pengumpulan data yang dilakukan dengan cara mengadakan suatu diskusi yang dilakukan secara sistematis dan terarah mengenai suatu isu atau masalah tertentu (Irwanto, 2006;1-2). FGD dilaksanakan untuk mengidentifikasi data-data yang sesuai dengan indikator konsep pariwisata bertanggung jawab dan juga untuk menyeleksi indikator yang sesuai dengan karakteristik lokasi penelitian. Kuesioner digunakan dalam FGD sebagai instrumen bantuan untuk mendapatkan data kuantitatif yang kemudian dianalisis menggunakan analisis SWOT.

\subsection{Analisis SWOT}

SWOT (strength, weakness, opportunity, threat) merupakan alat analisis yang umum digunakan untuk merumuskan strategi atas identifikasi berbagai faktor secara strategis berdasarkan pemahaman dan pengetahuan terhadap suatu objek (Utama \& Mahadewi, 2012: 150). Metode ini dilakukan berdasarkan 2 tingkat analisis yaitu analisis faktor internal tentang kekuatan dan kelemahan objek, serta analisis eksternal mengenai peluang dan ancaman yang relevan.

Menentukan faktor internal dan eksternal merupakan bagian penting dari proses perencanan strategis yang merupakan bagian dari pembangunan berkelanjutan (Reihanian et al, 2012: 225)

Faktor internal diidentifikasi sebagai kekuatan (S) atau kelemahan (W) dan faktor eksternal diidentifikasi sebagai peluang $(\mathrm{O})$ atau ancaman (T). Faktor $\mathrm{S}$ dan $\mathrm{W}$ selanjutnya dirurumuskan menjadi matriks internal strategy factor summary analysis (IFAS), sedangkan faktor $\mathrm{O}$ dan T menjadi matriks external strategy factor summary analysis (EFAS). Selanjutnya semua komponen dihitung bobot dan ratingnya dan kemudian skor akhir didapatkan. Berikut adalah langkah-langkah dari proses penilaian untuk $\mathrm{S}$ dan $\mathrm{W}$ :

1. Setiap faktor diberi koefisien antara 0,0 hingga 1,0 yang berturut-turut berarti tidak penting dan sangat penting. Angka ini menunjukkan signifikansi relatif dari masingmasing faktor dalam tingkat kesuksesan. Angka tersebut dinyatakan sebagai bobot dalam matriks IFAS.

2. Setiap faktor diberi rating antara 1 dan 4 , 1 berarti kelemahan mendasar, 2 berarti 
kelemahan minor, 3 sebagai kekuatan, dan 4 yang berarti kekuatan besar.

3. Untuk menentukan skor akhir masingmasing faktor, bobot faktor tersebut dikalikan dengan ratingnya.

4. Setelah semua skor akhir tiap faktor dihitung, skor tersebut dijumlahkan untuk menghitung skor akhir dari matriks IFAS.

5. Apabila skor akhir tersebut kurang dari 2,5 berarti kelemahan lebih besar dari kekuatan; jika lebih dari 2,5 maka kekuatan lebih besar dari kelemahan.

Langkah-langkah tersebut di atas kembali dilakukan untuk menyusun matriks EFAS. Apabila skor akhir kurang dari 2,5 maka peluang lebih kecil dari ancaman, sedangkan jika lebih dari 2,5 maka peluang lebih besar dari ancaman (Monavari, Karbasi, \& Mohooee, 2007)

\section{Hasil dan Pembahasan}

\subsection{Matriks Internal Strategy Factor Summary Analysis (IFAS)}

Terdapat total 3 faktor yang termasuk sebagai kekuatan dengan bobot setiap faktor sebesar 0,055 ; 0,061 ; dan 0,063 . Rating yang diperoleh berturutturut sebesar 3,0; 3,0; dan 3,5. Untuk kelemahan terdapat total 15 faktor dengan rentang bobot antara 0,045 hingga 0,063 . Rating yang diperoleh berkisar pada rentang 1,50 hingga 2,50. Berdasarkan hasil tersebut, faktor paling penting yang mendapatkan bobot terbesar adalah "menutup keran saat tidak digunakan". Faktor terpenting selanjutnya adalah berturut-turut "mematikan alat elektronik saat tidak digunakan", "memperbaiki kebocoran air", "menggunakan produk yang dapat didaur ulang", dan "memisahkan limbah sesuai kategori" dengan masing-masing memiliki bobot yang sama. Faktor yang dianggap paling tidak penting adalah "menyiram tanaman pada pagi/sore hari" dan "mengganti perlengkapan homestay tidak setiap

Tabel 1. Matriks IFAS

\begin{tabular}{|c|c|c|c|}
\hline $\begin{array}{ll}\text { Faktor Strategis Internal } \\
\end{array}$ & Bobot & Rating & Skor \\
\hline \multicolumn{4}{|l|}{ Kekuatan: } \\
\hline 1. Menutup keran saat tidak digunakan & 0.063 & 3.50 & 0.22 \\
\hline 2. Mematikan alat elektronik saat tidak digunakan & 0.061 & 3.00 & 0.18 \\
\hline 3. Optimalisasi penggunaan $\mathrm{AC}$ & 0.055 & 3.00 & 0.17 \\
\hline Sub total & & & 0.57 \\
\hline \multicolumn{4}{|l|}{ Kelemahan: } \\
\hline 1. Memperbaiki kebocoran air & 0.061 & 2.38 & 0.15 \\
\hline 2. Menggunakan tanaman asli yang menyimpan air & 0.059 & 1.50 & 0.09 \\
\hline 3. Menyiram tanaman pada pagi/sore hari & 0.049 & 2.25 & 0.11 \\
\hline 4. Menggunakan daun/rumput sebagai mulsa & 0.051 & 1.88 & 0.10 \\
\hline 5. Mengganti perlengkapan homestay tidak setiap hari & 0.049 & 2.38 & 0.12 \\
\hline 6. Mengukur jumlah air yang digunakan & 0.045 & 1.63 & 0.07 \\
\hline 7. Menggunakan lampu LED & 0.057 & 2.00 & 0.11 \\
\hline 8. Merawat alat elektronik secara berkala & 0.055 & 2.38 & 0.13 \\
\hline 9. Menghitung energi yang digunakan & 0.051 & 1.88 & 0.10 \\
\hline 10. Fasilitas tamu mendaur ulang & 0.053 & 1.63 & 0.09 \\
\hline 11. Menggunakan produk yang dapat didaur ulang & 0.061 & 1.88 & 0.11 \\
\hline 12. Mencetak dokumen seperlunya & 0.059 & 2.50 & 0.15 \\
\hline 13. Memisahkan limbah sesuai kategori & 0.061 & 1.63 & 0.10 \\
\hline 14. Menghitung jumlah limbah yang dihasilkan & 0.051 & 1.63 & 0.08 \\
\hline \multirow{2}{*}{ 15. Membeli produk ramah limbah } & 0.059 & 1.38 & 0.08 \\
\hline & & & 1.58 \\
\hline Total & 1 & & 2.15 \\
\hline
\end{tabular}


hari”. Skor akhir yang diperoleh matriks IFAS adalah sebesar 2,15 yang menunjukkan bahwa kelemahan lebih besar dari kekuatan. Perhitungan dari tahap ini dapat dilihat pada tabel 1 .

\subsection{Matriks External Strategy Factor Summary} Analysis (EFAS)

Dari hasil perhitungan terdapat 4 faktor yang termasuk peluang dan 10 faktor yang termasuk ancaman. Faktor peluang masing-masing memiliki bobot 0,$070 ; 0,070 ; 0,075$; dan 0,075

Dengan rating berturut-turut sebesar 2,75 ; 2,$75 ; 2,63$; dan 3,0. Faktor-faktor yang termasuk sebagai ancaman memiliki rentang bobot dari 0,036 hingga 0,077 dengan faktor "konflik internal antar masyarakat" sebagai faktor dengan bobot terendah. Faktor dengan bobot tertinggi diperoleh faktor "peran serta masyarakat dalam pariwisata", "penerapan teknologi informasi di area atraksi wisata", "keamanan dan keselamatan pengunjung", dan "keamanan lokasi objek wisata". Rating yang didapat berkisar antara 1,50 hingga 2,38. Skor akhir yang diperoleh sebesar 2,28. Dengan hasil ini maka dapat diketahui bahwa ancaman yang dihadapi lebih besar dibandingkan peluang yang dimiliki.
Perhitungan tahap ini dapat dilihat dalam tabel 2 .

\subsection{Matriks SWOT}

Tabel 3. Indeks Kuadran SWOT

\begin{tabular}{|c|c|c|}
\hline $\begin{array}{c}\text { Kuadran } \\
\text { SWOT }\end{array}$ & O-Peluang & T-Ancaman \\
\cline { 2 - 3 } & 0.81 & 1.47 \\
\hline S-Kekuatan & S-O & S-T \\
\hline 0.57 & 0.69 & 1.02 \\
\hline W-Kelemahan & W-O & W-T \\
\hline 1.58 & 1.20 & $\mathbf{1 . 5 2}$ \\
\hline
\end{tabular}

Gambar 1. Diagram Cartesius Dimensi SWOT

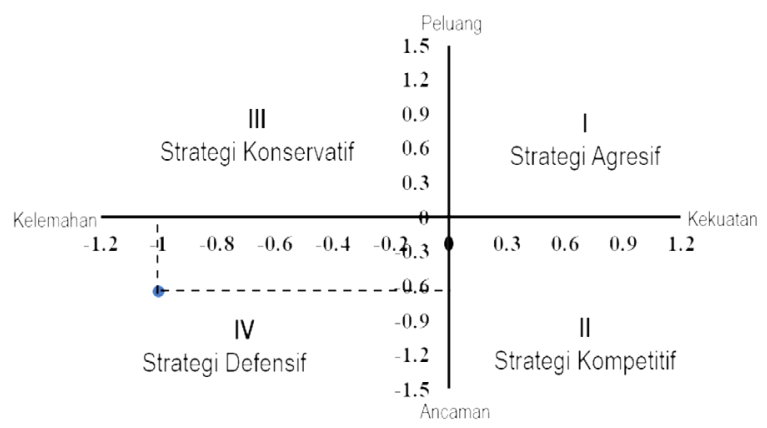

Tabel 2. Matriks EFAS

\begin{tabular}{|c|c|c|c|}
\hline $\begin{array}{ll}\text { Faktor Strategis Eksternal } \\
\end{array}$ & \multirow{2}{*}{ Bobot } & \multirow{2}{*}{ Rating } & \multirow{2}{*}{ Skor } \\
\hline Peluang: & & & \\
\hline 1. Pemandangan alam sekitar & 0.07 & 2.75 & 0.19 \\
\hline 2. Peran serta masyarakat dalam kegiatan pariwisata & 0.077 & 3.00 & 0.23 \\
\hline 3. Keanekaragaman pengunjung & 0.07 & 2.75 & 0.19 \\
\hline 4. Motivasi pengunjung & 0.075 & 2.63 & 0.20 \\
\hline Sub total & & & 0.81 \\
\hline Ancaman: & & & \\
\hline 1. Penerapan teknologi informasi di area atraksi wisata & 0.077 & 2.38 & 0.09 \\
\hline 2. Kualitas sumber daya manusia & 0.073 & 1.50 & 0.11 \\
\hline 3. Keamanan dan keselamatan pengunjung & 0.077 & 2.25 & 0.10 \\
\hline 4. Keamanan lokasi objek wisata & 0.077 & 1.88 & 0.12 \\
\hline 5. Lokasi objek wisata & 0.070 & 2.38 & 0.07 \\
\hline 6. Kebijakan pemerintah di bidang pariwisata & 0.073 & 1.63 & 0.11 \\
\hline 7. Bantuan atau dukungan pemerintah & 0.073 & 2.00 & 0.13 \\
\hline 8. Pengawasan masyarakat mengenai objek wisata & 0.075 & 2.38 & 0.10 \\
\hline 9. Konflik internal antar masyarakat & 0.036 & 1.88 & 0.09 \\
\hline 10. Kondisi perekonomian daerah & 0.075 & 1.63 & 0.11 \\
\hline Sub total & & & 1.47 \\
\hline Total & 1 & & 2.28 \\
\hline
\end{tabular}


Tabel 4. Strategi W-T

\section{Pelestarian Air}

a) Pelatihan pembuatan mulsa organik

b) Bekerja sama dengan instansi untuk pengadaan meteran air elektronik

c) Peningkatan kesadaran masyarakat dalam pelestarian air

d) Pelibatan wisatawan dalam usaha pelestarian air

2. Pengurangan dan Pengelolaan Limbah

a) Pelatihan pengelolaan limbah

b) Digitalisasi konten informasi

c) Pengadaan fasilitas daur ulang sederhana

d) Pemisahan limbah secara spesifik

3. Penggunaan Energi Secara Efisien

a) Bekerja sama dengan instansi untuk pengadaan lampu LED

b) Instalasi sensor cahaya

\subsection{Rekomendasi Strategi Pengembangan Titik Pandang Panenjoan}

\subsubsection{Pelestarian Air}

Dalam usaha untuk melakukan pelestarian air, terdapat 4 rekomendasi yang diberikan mengacu pada hasil dari analisis SWOT yang telah dilakukan. Rekomendasi yang pertama adalah pelatihan pembuatan mulsa organik. Penggunaan mulsa organik memiliki beberapa keunggulan dibandingkan mulsa anorganik yang berbahan dasar plastik. Mulsa organik dapat diperoleh secara gratis karena berasal dari sisa-sisa hasil pertanian yang kurang memiliki nilai ekonomis seperti sisa jerami padi, batang jagung, daun pisang dan tebu, dan serbuk gergaji. Bahan-bahan ini mudah terurai dan dapat menambah kandungan bahan organik dalam tanah.

Dalam buku Kamus Pertanian Umum, dijelaskan bahwa mulsa memiliki fungsi untuk melindungi tanah dari terpaan butiran hujan, mengurangi jumlah dan kecepatan aliran permukaan, menaikkan kapasitas infiltrasi tanah, meningkatkan permeabilitas tanah, dan meningkatkan simpanan air tanah. Mulsa juga dapat mengurangi penguapan air ke udara dan menahan penguapan tersebut sehingga air yang menguap jatuh kembali ke tanah dan intensitas penyiraman tanaman dapat dikurangi. Pelatihan pembuatan mulsa ini dapat diberikan oleh instansi yang bergerak di bidang pertanian.

Rekomendasi selanjutnya adalah dilakukannya kerja sama dengan instansi swasta atau pun pemerintah dalam pengadaan meteran air. Instalasi meteran air dapat digunakan untuk menghitung banyaknya jumlah air yang digunakan dalam satu hari. Data yang didapat dari hasil pengukuran dapat digunakan untuk menentukan target pengurangan penggunaan air secara berkala. Data penggunaan air dapat diletakkan di tempat yang dapat dilihat oleh semua orang untuk meningkatkan kesadaran masyarakat dan juga wisatawan.

Rekomendasi ketiga adalah peningkatan kesadaran masyarakat dalam pelestarian air. Sebelum usaha pelestarian air dilakukan, diperlukan penyamaan visi atau pandangan masyarakat mengenai pelestarian air. Penyamaan pandangan dapat dilakukan melalui pembekalan yang dilakukan secara rutin sebelum dimulainya kegiatan pelestarian air.

Setelah pandangan yang sama terbentuk, usaha pelestarian air dapat mulai dilakukan bersama-sama untuk memperoleh hasil yang optimal. Kegiatan yang dapat dilakukan adalah melakukan penanaman tanaman lokal yang dapat menyimpan air di pekarangan rumah. Salah satu tanaman lokal yang baik dalam menyimpan air adalah bambu. Zhou et al. (2005) mengatakan bahwa bambu memiliki beberapa manfaat dalam melestarikan air, yaitu dalam pengumpulan serasah, retensi atau penahanan kelembaban, dan intersepsi air hujan. Serasah adalah bahan organik mati berupa ranting dan daun bekas pangkasan yang dapat dijadikan pupuk4.

Kegiatan lain yang dapat dilakukan oleh masyarakat yang memiliki taman di lingkungan rumah adalah mulai menyirami taman sebelum pukul 10.00 atau sesudah pukul 16.00. Penyiraman tanaman dalam jangka waktu tersebut membuat air dapat diserap oleh tanaman dan terserap ke dalam tanah dengan lebih baik5. Kesadaran masyarakat juga perlu ditingkatkan perihal kebocoran air. Selama ini masyarakat yang menggunakan pompa air tentu menggunakan pipa sebagai media untuk mengalirkan air dari dalam sumur menuju ke tandon air dan kemudian dialirkan ke keran-keran yang 
ada di rumah. Sambungan pipa yang kurang rapat rawan menjadi sumber terjadinya kebocoran air. Dengan ditingkatkannya kesadaran masyarakat, diharapkan kebocoran air dapat dicegah melalui pengecekan pipa-pipa air secara rutin sehingga air yang terbuang percuma dapat diminimalkan.

Rekomendasi terakhir adalah pelibatan wisatawan dalam usaha pelestarian air. Wisatawan memegang peranan penting dalam usaha pelestarian air di Titik Pandang Panenjoan karena wisatawan secara langsung juga ikut serta dalam penggunaan sumber daya air yang ada. Wisatawan yang datang mengunjungi Titik Pandang Panenjoan juga dapat diajak untuk turut serta dalam usaha pelestarian air. Salah satu usaha yang dapat dilakukan wisatawan adalah dengan cara mengikuti kebijakan pengelola dalam hal penggantian handuk dan linen yang tidak setiap hari. Dengan melakukan penggantian setelah beberapa hari, maka air yang digunakan untuk mencuci handuk dan linen tersebut dapat dihemat. Wisatawan juga dapat ikut serta dengan menggunakan air secukupnya saat mencuci tangan mau pun saat mandi.

\subsubsection{Pengurangan dan Pengelolaan Limbah}

Rekomendasi pertama dalam usaha untuk mengurangi dan mengelola limbah adalah adalah pengadaan fasilitas daur ulang sederhana yang dapat digunakan juga oleh wisatawan. Daur ulang adalah upaya untuk memproses bahan-bahan yang telah dipakai agar mendapatkan produk baru. Daur ulang dapat mencegah limbah dari bahan yang berpotensi bermanfaat dan mengurangi konsumsi bahan baku mentah sehingga mengurangi penggunaan energi, polusi udara dari pembakaran sampah, dan polusi air. Daur ulang merupakan salah satu bagian ketiga dari hierarki sampah yang terdiri dari reduce atau mengurangi, reuse atau menggunakan kembali, dan yang terakhir yaitu recycle atau mendaur ulang (Lienig dan Bruemmer, 2017: 197). Selain menghasilkan produk baru, proses daur ulang juga dapat meningkatkan nilai manfaat dan bahkan nilai ekonomis dari limbah tersebut.

Salah satu contoh fasilitas daur ulang limbah sederhana yang dapat dibuat di Titik Pandang Panenjoan adalah model keranjang kompos takakura. Sesuai namanya, model keranjang ini ditemukan oleh seorang ahli dari Jepang bernama Mr. Koji Takakura yang bekerja sebagai koordinator di Wakamatsu Environment Research Institute6. Keranjang ini berfungsi sebagai komposter untuk mendaur ulang limbah organik menjadi pupuk kompos. Pembuatan keranjang ini sangat mudah karena bahan untuk membuatnya tidak sulit untuk dicari. Alat dan bahan yang dibutuhkan yaitu sekop kecil, keranjang, sekam, starter kompos, air, dan sampah organik. Dengan adanya metode ini, wisatawan yang datang juga dapat ikut serta melakukan kegiatan daur ulang.

Rekomendasi kedua adalah mengadakan pelatihan pengelolaan limbah. Pengelolaan limbah merupakan suatu usaha untuk mengendalikan jumlah limbah dalam batas wajar untuk menjaga kenyamanan lingkungan sekitar. Pengelolaan sampah di suatu daerah harus disesuaikan dengan karakteristik daerah tersebut. Berdasarkan observasi, karakteristik Desa Tamanjaya adalah merupakan desa dengan kepadatan penduduk rendah, memiliki infrastruktur yang terbatas, kondisi geografis yang beragam, dan aksesibilitas transportasi yang terbatas.

Dalam pelatihan pengelolaan limbah ini, dapat disampaikan beberapa hal mengenai aspekaspek yang berpengaruh dalam pengelolaan limbah. Beberapa aspek tersebut adalah aspek peraturan, aspek kelembagaan, aspek sosial budaya, aspek pendanaan, dan aspek teknologi. Untuk dapat meraih hasil yang optimal, diperlukan sinergi dan kontribusi aktif dari masyarakat dan instansi baik pemerintah daerah mau pun pihak swasta. Beberapa metode pengelolaan limbah yang dapat diajarkan kepada masyarakat adalah metode komposter takakura, drum komposter, drum tertanam, wadah sampah desa atau wasades, dan pengepul atau bank sampah.

Rekomendasi ketiga adalah digitalisasi konten informasi. Digitalisasi konten informasi mengenai Titik Pandang Panenjoan dapat mengurangi penggunaan media cetak di atas kertas. Konten-konten yang sifatnya informatif mengenai Titik Pandang Panenjoan dapat disampaikan melalui media lain salah satunya adalah tablet yang disediakan atau juga dapat melalui kode QR yang dapat dipindai oleh masing-masing wisatawan melalui ponsel pintarnya.

Kode QR atau $Q R$ code adalah kependekan dari quick response code yang merupakan sebuah teknologi yang muncul sebagai hasil 
dari keterbatasan fitur teknologi dari bar code atau kode batang. Kode QR merupakan sebuah alat komunikasi dan sebuah perantara baru yang membentuk jembatan antara teknologi digital dan media komunikasi tradisional (Akta, 2017: 29). Kode QR mampu menyimpan tautan yang berupa situs internet, nomor telepon, alamat, atau pun kartu nama. Dengan digunakannya kode QR di Titik Pandang Panenjoan maka wisatawan dapat mengakses informasi yang diinginkan langsung dari ponsel pintar mereka masing-masing sekaligus mengurangi penggunaan media cetak.

Rekomendasi terakhir adalah pemisahan limbah secara spesifik. Secara umum limbah dibedakan menjadi 2, yaitu limbah organik atau limbah yang dapat diuraikan melalui proses biologi secara sempurna karena berasal dari zat-zat hidup, dan limbah anorganik atau limbah yang tidak dapat diuraikan oleh proses biologi. Limbah anorganik terbagi lagi menjadi limbah anorganik yang dapat didaur ulang dan limbah anorganik yang tidak dapat didaur ulang. Limbah anorganik dapat didaur ulang kembali apabila memiliki nilai ekonomis.

Pemisahan limbah secara lebih spesifik di Titik Pandang Panenjoan dapat mempermudah dalam pengolahan limbah tersebut lebih lanjut. Limbah organik berupa dedaunan atau rerumputan dapat diolah menjadi pupuk kompos, sedangkan limbah organik berupa sisa makanan dapat diolah menjadi pakan ternak. Limbah anorganik dapat dipisahkan dengan lebih spesifik lagi seperti yang dilakukan di Jepang. Limbah anorganik dipisahkan menjadi 6 kategori yaitu kertas bekas, botol dan kaleng makanan minuman, botol plastik PET (Polyethylene Terephthalate), baterai bekas, kotak karton susu, dan wadah stirofoam7. Pemisahan ini dapat memudahkan proses daur ulang limbah tersebut dan juga membuat limbah dapat lebih mudah diukur berdasarkan berat atau volumenya.

\subsubsection{Penggunaan Energi Secara Efisien}

Rekomendasi pertama untuk menciptakan penggunaan energi yang lebih efisien adalah dengan mengganti bohlam biasa dengan bohlam LED. Lampu LED atau Light-Emitting Diode adalah peralatan elektronik yang sangat kecil yang menghasilkan cahaya melalui sifat semikonduktor dari sekeping metal (Latifah, 2015). Lampu LED memiliki usia pakai yang lebih panjang dibandingkan dengan lampu biasa. Lampu biasa biasanya memiliki usia pakai selama kurang lebih 1.000 jam, sedangkan lampu LED memiliki usia pakai antara 25.000 hingga 45.000 jam. Selain itu, secara umum lampu LED menggunakan daya listrik dalam jumlah yang lebih sedikit dibandingkan lampu biasa yaitu hingga $85 \%$ lebih hemat dari lampu biasa. Kedua hal ini dapat mengurangi biaya penggantian dan biaya operasional lampu yang digunakan.

Penggantian lampu LED ini dapat dilakukan secara bertahap, dimulai dari fasilitas-fasilitas umum seperti musholla, toilet, dan museum konservasi yang ada di Panenjoan. Setelah penggantian lampu LED di fasilitas umum selesai dilakukan, bohlam lampu di rumah-rumah warga juga dapat dilakukan penggantian ke lampu LED. Agar semakin banyak rumah warga yang dapat dilakukan penggantian, kerja sama dapat dilakukan dengan pemerintah daerah atau pihak swasta untuk mendapatkan bantuan dalam pengadaan lampu LED.

Rekomendasi kedua adalah dilakukannya instalasi alat pengatur waktu atau sensor cahaya. Pemasangan alat pengatur waktu dan sensor cahaya dapat mengefisienkan penggunaan listrik untuk sarana penerangan. Sensor cahaya bekerja untuk mematikan mau pun menghidupkan lampu secara otomatis berdasarkan cahaya yang masuk. Apabila cahaya yang masuk ke dalam sensor terang, maka lampu akan hidup secara otomatis. Sedangkan apabila cahaya yang masuk ke dalam sensor sedikit atau hari sudah mulai gelap, makan lampu akan mati secara otomatis. Dengan adanya sensor ini, maka daya atau energi listrik yang ada dapat digunakan secara tepat waktu dan efisien sehingga meminimalkan energi yang terbuang percuma. Tagihan pembayaran listrik kemudian dapat dibandingkan antara sebelum pemasangan sensor cahaya dan setelah pemasangan. Beberapa area yang dapat dilakukan instalasi sensor cahaya adalah di lampu penerangan jalan dan lampu hias bertuliskan Taman bumi Ciletuh-Palabuhanratu.

Rekomendasi-rekomendasi di atas diharapkan dapat menjadi masukan bagi pengelola Titik Pandang Panenjoan, terutama PAPSI beserta para pemangku kepentingan lain yang terlibat di dalamnya untuk dapat mengembangkan atraksi wisata tersebut sesuai dengan apa yang diharapkan dengan memperhatikan aspek-aspek dalam 
pariwisata bertanggung jawab. Penerapan aspekaspek tersebut diharapkan dapat memberi manfaat bagi masyarakat dan wisatawan dengan harapan utama dapat menjaga kelestarian lingkungan dari kerusakan yang mungkin ditimbulkan dari berkembangnya kegiatan pariwisata di Titik Pandang Panenjoan.

\section{Kesimpulan}

Kesimpulan yang didapat dari penelitian ini adalah posisi internal dan eksternal Titik Pandang Panenjoan dalam penerapan konsep pariwisata bertanggung jawab masih di bawah rata-rata. Hal ini dapat dibuktikan dari skor yang diperoleh melalui matriks IFAS dan EFAS yaitu sebesar 2,13 dan 2,28. Kedua skor ini masih di bawah nilai ratarata yang sebesar 2,5. Apabila kedua skor tersebut dianalisis dalam matriks internal-eksternal, dapat diketahui bahwa posisi Titik Pandang Panenjoan terletak dalam kuadran 5 yang berarti objek perlu melakukan strategi stabilitas.

Dengan posisi objek sedemikian rupa, strategi yang tepat untuk diterapkan di Titik Pandang Panenjoan adalah strategi yang bersifat defensif untuk meminimalkan kelemahan dan mengatasi ancaman yang ada. Strategi yang dirumuskan dari matriks SWOT berfokus pada aspek pelestarian air, penggunaan energi secara efisien, dan aspek pengurangan dan pengelolaan limbah, sehingga dampak negatif dari meningkatnya kunjungan wisatawan ke Titik Pandang Panenjoan dapat diminimalkan. Beberapa rekomendasi strategi yang dapat dilakukan adalah peningkatan kesadaran masyarakat dan pelibatan wisatawan dalam pelestarian air, kerja sama dengan instansi dalam pengadaan meteran air dan bohlam LED, pengadaan fasilitas daur ulang sederhana, mengadakan pelatihan pengelolaan limbah, dan digitalisasi konten informasi.

\section{Daftar Pustaka}

Aktas, Celalettin. 2017. The Evolution and Emergences of QR Code. Newcastle: Cambrigde Scholars Publishing

Badan Pusat Statistik Provinsi Jawa Barat. 2014. "Jawa Barat Dalam Angka 2014”, Provinsi Jawa Barat.

Budeanu, A., 2005. Impacts and responsibilities for sustainable tourism: a tour operator's perspective.
J. Clean. Prod. 13 (2), 89-97

Bramwell, B., Lane, B., McCabe, S., Mosedale, J., Scarles, C., 2008. Research perspectives on responsible tourism. J. Sustain. Tour. 16 (3), 253-257.

Chen, Lu, dan Young C.Y. Ng. 2015. The Principle of Geotourism. Beijing: Springer Geography

Cooper, C., Fletcher, J., Gilbert, D., \& Wanhill, S. 1993. Tourism Principles and Practice. Pitman Publishing

Darsiharjo, Supriatna, U., dan Saputra, M.I. 2016. "Pengembangan Taman bumi Ciletuh Berbasis Partisipasi Masyarakat sebagai Kawasan Geowisata di Kabupaten Sukabumi”. Jurnal Manajemen Resort dan Leisure 13. 55-60.

Goodwin, H. 2011. Taking Responsibility for Tourism. Goodfellow Publishers, Limited.

Hall, M., 2012. Governance and responsible tourism. In: Leslie, D. (Ed.), Responsible Tourism. Concepts, Theory and Practice. CABI, Wallingford, pp. 107118

Hendratno, Agus. 2002. "Perjalanan Wisata Minat Khusus Geowisata Gunung Merapi: Studi di Lereng Merapi Bagian Selatan, Yogyakarta”. Jurnal Nasional Pariwisata 2. 7-23.

Irwanto. 2006. Focused Group Discussion (FGD): Sebuah Pengantar Praktis. Jakarta: Yayasan Obor Indonesia.

Joyosuharto, Sunardi. 1995. Dasar-Dasar Manajemen Kepariwisataan Alam. Yogyakarta: Liberty

Krippendorf, J. (1987). Ecological approach to tourism marketing. Tourism Management, 8(2), 174-176

Latifah, N. L. 2015. Fisika Bangunan 2. Jakarta: Griya Kreasi.

Leslie, David. 2012. Responsible Tourism: Concept, Theory, and Practice. Cambridge: CABI.

Lienig, J., dan Bruemmer, H. 2017. Fundamentals of Electronic Systems Design. Cham: Springer

Manente, M., Minghetti, V., \& Mingotto, E. 2014. Responsible Tourism and CSR: Assessment Systems for Sustainable Development of SMEs in Tourism. London: Springer.

Monavari, M., Karbasi, A., \& Mogooee, R. (2007). Environmental strategic management. Tehran: Kavoush Qalam, Iran.

Newsome, David. 2005. Geotourism: Sustainability, Impacts, and Management. Oxford: Elsevier Butterworth-Heinemann

Nurazizah, Sabrina. 2014. "Penerapan Pariwisata Bertanggung Jawab Di Desa Wisata Nglinggo, Desa Pagerharjo, Kecamatan Samigaluh, Kabupaten Kulon Progo, Daerah Istimewa Yogyakarta”. Skripsi. Yogyakarta: Program Studi Pariwisata, Fakultas Ilmu Budaya, Universitas 
Gadjah Mada.

Peraturan Daerah Kabupaten Sukabumi Nomor 4 Tahun 2016 Tentang Rencana Pembangunan Jangka Menengah Daerah Kabupaten Sukabumi Tahun 2016-2021, tidak diterbitkan. (Diunduh via http://bappeda.sukabumikab.go.id/Download/ RPJMD20162021.pdf tanggal 30 Maret 2017)

Rangkuti, Freddy. 1997. Analisis SWOT: Teknik Membedah Kasus Bisnis. Jakarta: Gramedia Pustaka Utama.

Rosana, M. F. 2016. Ciletuh-Palabuhanratu Taman bumi Towards UNESCO Global Taman bumis. Bandung: Unpad Press.

RTP, 2002. Cape Town Declaration on Responsible Tourism. Responsible Tourism Partnership. Diakses pada 14 Oktober 2018 via: http://www. responsibletourismpartnership.org/RTWorld.html

Savitri, Dotika. 2013. "Strategi Pengembangan Wisata Karst Kalisuci melalui Pendekatan Prinsip Ekowisata". Skripsi. Yogyakarta: Program Studi Pariwisata, Fakultas Ilmu Budaya, Universitas Gadjah Mada.

Scriven, L., dan van der Watt, H. 2014. Responsible Tourism in Cape Town: How-To Guide. Cape Town: City of Cape Town Tourism Department.

Smith, R. A. (1992). Beach resort evolution: Implications for planning. Annals of Tourism Research, 304322

Spenceley, Anna. 2008. Responsible Tourism: Crictical Issues for Conservation and Development. London: Earthscan.

Stanford, D. (2000). A review of the education of tourists to achieve sustainable tourism. Lancaster: Lancaster University

Stanford, D., 2008. Exceptional visitors: dimensions of tourist responsibility in the context of New Zealand. J. Sustain. Tour. 16 (3), 258-275

Sunaryo, Bambang. 2013. Kebijakan Pembangunan Destinasi Pariwisata. Yogyakarta: Gava Media.

Swarbrooke, John. 1999. Sustainable Tourism Management. London: CABI Publishing

Tim Penyusun Kamus PS. 2013. Kamus Pertanian Umum. Jakarta: Penebar Swadaya.

UNESCO. 2016. UNESCO Global Taman bumis. Celebrating Earth Heritage, Sustaining Local Communities

Utama, I. G. B. R., dan Mahadewi, N. M. E. 2012. Metodologi Penelitian Pariwisata \& Perhotelan. Yogyakarta: Penerbit Andi.

Wheeller, B. (1990). Responsible tourism. Tourism Management, 11(3), 262-263

\section{Endnotes}

1) http://ciletuhpalabuhanratugeopark.org/ diakses pada 31 Maret 2017 pukul 22.27

2) Data papsi, 2017

3) Taman Bumi Ciletuh-Palabuhanratu bersama dengan 12 taman bumi lain dari berbagai negara secara resmi diakui sebagai bagian dari UNESCO Global Geopark oleh Dewan Eksekutif UNESCO pada 17 April $2018 \mathrm{http} / /$ www.unesco.org/new/en/naturalsciences/environment/earth-sciences/unesco-globalgeoparks/new-unesco-global-geoparks/ diakses pada 30 Mei 2017 pukul 23.20

4) https://kbbi.kemdikbud.go.id/entri/serasah diakses pada 16 April 2018 pukul 03.04

5) https://www.rodalesorganiclife.com/garden/ watering-smart diakses pada 1 April 2018 pukul 23.10

6) The passion of a Japanese researcher who dedicates his life to the dissemination of the "magic bucket, diakses melalui http://www.eco-csrjapan.go.jp/en/ jpec.html, pada 4 april 2018 pukul 20.39

7) http://www.imccsub.com/tentang-jepang/jepangmodern/229-bagaimanakah-sistem-pembuangansampah-di-jepang.html diakses pada 2 April 2018 pukul 21.04 